NBER WORKING PAPER SERIES

\title{
MACROECONOMIC ADJUSTMENT AND THE HISTORY OF CRISES IN OPEN ECONOMIES
}

Joshua Aizenman

Ilan Noy

Working Paper 18527

http://www.nber.org/papers/w18527

\author{
NATIONAL BUREAU OF ECONOMIC RESEARCH \\ 1050 Massachusetts Avenue \\ Cambridge, MA 02138 \\ November 2012
}

We thank Amy Wood and Zack Dorner for excellent research assistance. We also thank audiences at Victoria University and the JIMF 30th Anniversary conference, Fordham University, NY, especially Harris Dellas, Michael King, Jim Lothian and Michael Melvin. The views expressed herein are those of the authors and do not necessarily reflect the views of the National Bureau of Economic Research.

NBER working papers are circulated for discussion and comment purposes. They have not been peerreviewed or been subject to the review by the NBER Board of Directors that accompanies official NBER publications.

(C) 2012 by Joshua Aizenman and Ilan Noy. All rights reserved. Short sections of text, not to exceed two paragraphs, may be quoted without explicit permission provided that full credit, including $\mathbb{C}$ notice, is given to the source. 
Macroeconomic Adjustment and the History of Crises in Open Economies

Joshua Aizenman and Ilan Noy

NBER Working Paper No. 18527

November 2012, Revised January 2013

JEL No. E2,E4,F3,F36,F41

\begin{abstract}
This paper investigates the impact of the history of crises on macroeconomic performance. We first study the impact of past banking crises on the probability of a future banking crisis. Applying data for 19802010 for all countries for which the required information is available, controlling for conventional macro variables and the history of banking crises occurring after 1970, we do not detect a learning process from past banking crises. Countries that have already experienced one banking crisis generally have a higher likelihood of experiencing another crisis; and the depth of the present crisis does not appear to be affected by the previous historical experience with crisis events. Evidence also suggests that, in middle-income countries, higher de jure capital account openness is associated with lower likelihood of a banking crisis, a lower ratio of nonperforming loans during the crisis, and higher levels of forgone output in the crisis' aftermath.

In contrast, we find that past crisis experience has a significant impact on savings. When facing considerable political risk, the past does seem to matter - countries with more people who were exposed, over their lifetime, to larger disasters will tend to save more. This association, however, does not hold for countries with more stable political systems. We interpret these results as consistent with a differential sectoral adjustment to a crisis hypothesis. The private sector, by virtue of its harder budget constraints, adjusts faster, whereas the government adjusts at a slower pace following a crisis. The financial sector may find itself in between the two. The "too big to fail" doctrine associated with large banks provides them with a softer budget constraint, delaying the day of adjustment; for some, delaying bankruptcy. Occasionally, the separation between banks and the public sector is murky, further delaying necessary adjustments of the financial sector.
\end{abstract}

\author{
Joshua Aizenman \\ Department of Economics; E2 \\ 1156 High St. \\ University of California, Santa Cruz \\ Santa Cruz, CA 95064 \\ and NBER \\ jaizen@ucsc.edu \\ Ilan Noy \\ Saunders Hall 542 \\ 2424 Maile Way \\ University of Hawaii, Manoa \\ Honolulu, HI 96822 \\ noy@hawaii.edu
}




\section{Introduction}

The global crisis of 2008-9 and the ongoing Euro crisis raise intriguing questions regarding the long-term response to crises. Sectors and agents with no access to alternatives respond and adjust faster than parties that have the ability to delay their adjustment. Household that loose access to credit, for example, are forced to adjust, and transition to zero, or positive saving. In contrast, agents that retain greater access to the capital markets may choose to delay their adjustment. Postponed adjustment may be facilitated by access to funding supported by state guarantee, or by fiat (say printing money). Delayed adjustment may be preferable as it entails the option value of good news ("gambling for resurrection"), ${ }^{1}$ and smoother adjustment may be less costly. Furthermore, delayed adjustment may help in negotiations regarding who will adjust more. ${ }^{2}$ In these circumstances, a party that has better access to the capital market may end up with greater leverage in the bargaining game, shifting the burden of adjustment to other parties. ${ }^{3} \mathrm{~A}$ different set of questions revolves around the long-term memory this adjustment process generates. How long will actors persist in their new behavior or alternatively if and when do they revert back to a previous mindset.

The recent patterns of adjustment observed in the US and the Euro zone countries suggest that the household adjusted faster than the public sector and the regulators. The growing financial segmentation induced by the crises has been manifested in disappearing credit, pushing a growing share of households into 'deleveraging'. In contrast, the federal government in the US increased its borrowing, mitigating partially the recessionary impact of private deleveraging. In the Euro zone, even governments confronting rapidly increasing sovereign spreads opted for delayed adjustment. This delay was supported by the ECB (where public debt held by private banks was taken as a collateral), and by the national banking systems, facilitating 'banking' local governments. These patterns are consistent with the conjecture of differential sectoral adjustment: the private sector, by virtue of its harder budget constraints, adjusts faster, whereas the government adjusts at a slower pace

\footnotetext{
${ }^{1}$ See Hellmann, Murdock and Stiglitz (2000) for the economics of gambling for resurrection.

${ }^{2}$ When a fundamental crisis occurs, key stakeholders are locked in a war of attrition, attempting to minimize their adjustment burden. Who will adjust, and by how much? Creditors, debtors, or taxpayers? See Alesina and Drazen (1991).

${ }^{3}$ See Perotti and Spier (1993) and Mitra (1999) for the impact of access the capital market and liquidity on bargaining clout.
} 
in the aftermath of the crisis. The financial sector may find itself in between the two. The "too big to fail" doctrine associated with large banks provides them with softer budget constraint, delaying the day of adjustment (for example, delaying bankruptcy). Occasionally, the separation between banks and the public sector is murky, further delaying the painful adjustment of the financial sector.

The differential adjustment hypothesis raises intriguing questions about the burden of history, and its impact on macroeconomic dynamics following crises. An example of such history dependent dynamics and its importance for public policy include a traumatic adjustment of the private sector that may affect the future private saving rates of household impacted adversely by a 'cold turkey' switch from borrowers to savers, and bankruptcy. In contrast, postponing the adjustment by the public sector puts the country in the peril of fiscal myopia, of adjust tomorrow, 'but tomorrow never comes.' The clash between these two modes of adjustment may induce the syndrome of lost decades of growth (e.g., the 1980s in Latin America). The delayed adjustment of the public sector, manifested in terms of postponing cleaning the balance sheets and tightening financial regulations, may increase the susceptibility of the economy to future crises.

The impact of crises on households' adjustment may be greater in middle income countries, and in countries with a larger middle class. In these countries, the share of households losing access to credit markets at times of peril is greater. This is the case if the shallow financial intermediation and costly enforcement of contracts in poor countries implies that most households are credit constrained even in normal times. In contrast, in richer countries and with greater income equality, a larger segment of the population is less reliant on external borrowing to finance its consumption and investment.

The purpose of our paper is to explore the degree to which the differential adjustment hypothesis is consistent with the experience of most countries in recent decades. As testing all the implications of this hypothesis is beyond the scope of a single paper, our study focuses on two narrower questions:

The first is the degree to which past banking crises affect the probability of future crises. Delayed adjustment of the public and the financial sectors, 'kicking the can,' implies that past crises may not affect, or even increase the probability of future crises. In contrast, efficient and fast adjustment the public and the financial sectors may reduce the probability of future banking crises. 
Secondly, we study the degree to which past crises increase the saving rates of the affected households, as will be the case if painful past adjustment increases the demand for precautionary saving, and the proliferation of 'neither a borrower nor a lender be' attitude among the middle class.

Overall, our results are consistent with history dependent dynamics, and a differential adjustment process between the private and public sectors. Specifically, we find evidence that the experience of past crises in middle income countries with considerable political risk tend to increase savings. Intriguingly, we failed to find learning from past banking crises -banking crises seem not to elicit learning, and past occurrence may even increase the probability of future crises. Sections 2 and 3 detail the previous literature and our research on the adjustment of the financial and public sector to the occurrence of banking crises, respectively, while section 4 focuses on the question of saving and households exposure to past income catastrophes. We close with a discussion of limitations and policy ramifications of our results, and outline open questions deserving further investigation.

\section{Literature on the Determinants of Banking Crisis}

The empirical literature on the determinants of banking crises is quite voluminous. The theoretical literature is far too extensive to be covered here, and since our contribution is empirical in nature, we focus herein only on empirical investigations of banking crises. Generally, one can distinguish two different strands in this empirical banking crises literature. A first strand investigates the process that leads to the occurrence of banking crises, the second focuses on the depth of the financial crisis, once it occurs, and examines its characteristics. We focus on these aspects, occurrence and magnitude, in our own investigation of the adjustment to past events.

\subsection{Occurrence}

Arteta and Eichengreen (2002) provide a decade-old extensive survey of empirical macroeconomic research on banking crises that uses mostly cross-country panel frameworks to assess the likelihood for the occurrence of banking crises; either as an exercise whose aim is to develop early-warning-systems or to assist in developing preventive measures that may inhibit the occurrence of these crises. They identify a list of 
macroeconomic and financial variables that are found to be significant in the determination of banking crises. ${ }^{4}$

A number of papers have taken a different approach to the research on the causes of banking distress and have utilized firm-level data sets on financial institutions' balance sheets. Bongini et al. (2001) examine the evolution of the East Asian crisis, which was accompanied by large-scale banking problems as do Levy-Yeyati and Micco (2007) for Latin American banks. They find that, for example, foreign-owned banks were less likely to get into a liquidity crisis in the first case and that foreign penetration lowered financial fragility more generally in the latter case. These empirical models that rely on micro-data are more detailed, can assess the importance of the banks' balance sheets, and can differentiate between banking performance within a single country (as the banking sector crisis does not imply a universal failure of all banks). However, these micro-results are probably less generalizable and are also less relevant for work that is focussed on the general vulnerability of an economy to a systemic banking crisis rather than of individual banks. As such, we focus on the cross-country panel framework rather than attempt to test any of our hypotheses within a micro-level balance-sheet dataset for individual banks.

\subsection{Depth}

Most of this work focuses on measuring the depth of the post-crisis economic downturn, typically measured as GDP deviation from a calculated trend that results from a banking crisis (e.g., Hutchison and Noy, 2005). There is significantly less work on the determinants of these output collapses, however. Recently, Berkman et al. (2012) estimated the depth of the downturn following the global financial crisis, assuming that the crisis hit all high- and middle-income countries. They find that countries with more leveraged domestic financial systems, stronger credit growth, and more short-term debt experienced larger declines in economic activity. ${ }^{5}$

\footnotetext{
${ }^{4}$ Earlier papers that also developed cross-country panel models predicting the likelihood of banking crises are Demirgüç-Kunt and Detragiache (1998), Kaminsky and Reinhart (1999), and Glick and Hutchison (2001); while there are also many later papers using similar frameworks (e.g., Schaeck et al., 2009 ).

${ }^{5}$ In Berkman et al. (2012), the depth is measured not as GDP deviations from trend but rather as the actual post-crisis GDP growth experience relative to the pre-crisis forecast.
} 
Serwa (2010) on the other hand, focuses on the interaction between the size of the crisis (measured using several monetary aggregates) and the GDP declines that follow it, and maybe not surprisingly, observes a positive correlation between the two variables. ${ }^{6}$

Cecchetti et al. (2012) also pursue a similar line of research and examine whether pre-crisis conditions mattered for the depth of the downturn following the 2007-2009 global financial crisis. We are not aware of any work that attempts to examine the determinants of the depth of a banking crisis (proxied either by banking sector aggregates or the crisis consequences) in general, nor, of course, with any specific focus on the question of adjustment and the learning from past experience done by the regulators, policy makers and banking institutions.

\section{Data, Models, and Results - History and Banking Crises}

\subsection{Model I-panel of country-year observations}

We estimate the probability of occurrence of a banking crisis using a panel crosscountry dataset for banking crises based on the newly updated banking crises database of Laeven and Valencia (2012). Older versions of this data are the most widely used in projects that identify the occurrence of banking crises; the year in which they started, their duration, and their depth (using several measures - more on that in section 3.4). We use data for 1980-2010 for all countries for which the required data is available. ${ }^{7}$ We estimate a multivariate probit specification of the likely occurrence of a banking crisis (BKC). We postulate a probit model of the form:

$$
\left[\operatorname{prob}\left(B K C_{i t}=1\right)\right]=F\left(\alpha_{i}+\beta X_{i t-1}+\delta B K C_{i t}^{H I S T}+\gamma C C_{i t}^{H I S T}\right)
$$

\footnotetext{
${ }^{6}$ In practical terms, Serwa (2012) examines the correlation between these monetary aggregates and the real economy, rather than have a specific focus on banking crises (although the paper uses only data from banking crisis episodes).

${ }^{7}$ We are interested in the importance of banking crises history; the Laeven and Valencia (2012) dataset details banking crises occurring after 1970 , so we begin our sample a decade later.
} 
where $B K C$ is a binary variable denoting onset of a banking crisis (the year the crisis started - as defined by Laeven and Valencia, 2012), $\alpha_{i}$ is the country-fixed-effect, $X$ is a vector of macroeconomic and financial independent variables, and $B K C_{i t}^{\text {HIST }}$ and $C C_{i t}^{\text {HIST }}$ are binary measures denoting whether a previous banking or currency crisis occurred in country $i$ during the previous decade (respectively). We estimate the model using LIMDEP's routine for estimation of probit models with and without fixed effects (for all details, see Greene, 2012, ch. E27).

We distinguish between high- and middle-income countries. ${ }^{8}$ For control $\left(X_{i t-1}\right)$ variables, we rely on previous recent research; in particular on Noy (2004), Demirgüç-Kunt and Detragiache (2005), von Hagen and Ho (2007), Joyce (2011), and Duttagupta and Cashin (2011). The list of independent variables we use is: per capita GDP, real GDP growth rate, a binary variable denoting hyperinflation (annual $\mathrm{CPI}>40$ ), the de facto flexibility of the exchange rate regime, a measure of bank liquidity (deposit money bank assets as \% of GDP), credit expansion (growth rate of deposit money bank assets), and the degree of openness of the capital account (the Chinn-Ito de jure index). ${ }^{9}$ Because the occurrence of the crisis will affect all of these variables, they are included in the specification with a one-year lag.

In addition to these variables, we add two others: the history of banking crises for each country (a binary indicator whether a banking crisis occurred in the previous decade), and a similar measure of the history of currency crises. ${ }^{10}$ None of the papers previously mentioned (nor any others as far as we know) uses the new data that includes the global financial crisis of 2008-2010 (GFC henceforth), and none attempted to use the historical exposure variables that we include.

We estimate the model with and without country fixed effects; the fixed effects control for time-invariant differences across countries, and also remove a lot of the institutional, political, and supervisory variance in the data given the infrequent occurrence of banking

\footnotetext{
${ }^{8} \mathrm{High}$ income countries are defined as countries whose GDP per capita is bigger than 11,000 (in 2000US\$) while middle income countries are those whose GDP per capita is bigger than 1,000 but lower than 11,000 (in 2000US\$).

${ }^{9}$ Two other control variables were considered as they were included in some of the papers cited above, but both variables are not included in the specifications we present as they were never statistically significant: the real interest rate (nominal interest rate minus $\mathrm{CPI}$ ) and the foreign exchange open position (foreign reserves /M2).

${ }^{10}$ Since the two types of financial crises frequently occur together; this was dubbed 'twin' crisis by Kaminsky and Reinhart (1999).
} 
crises. When including fixed effects, we also add a heteroskedacticity correction, but this does not change our results in any material way.

\subsection{Results for model I}

We investigate separately the incidence of banking crises in high- and middle-income countries for 1981-2010; and as part of our investigation, we also separate a sample from the most recent financial crisis of 2008-2010. We start by describing our data separately for these three sub-samples (see table 1). One noteworthy observation is that once we include the data from the most recent years, the frequency of banking crises is not any different between high- and middle-income countries. Historically, though, the middle-income countries were more exposed to banking crises ( $29 \%$ of the middle income sample are of observations that followed a banking crisis within a decade, while the figure for the high income sample is $16 \%$ ). The other differences between the sub-samples are to be expected; real GDP growth rate is lower, on average, in high income countries, while their capital account is significantly more open, $\mathrm{M} 2$ is higher, as is our measure of credit.

\section{INSERT TABLE 1}

For our regressions, we start our discussion with the results for high income countries. In table 2 column 1, we include the full high-income sample (597 observations, 28 countries) without country-effects. The model appears to be moderately useful in predicting banking crises, with a pseudo $R^{2}$ of 0.29 . We find that the banking-history variable enters with a positive coefficient, i.e., a previous experience with banking crises increases the likelihood of another one occurring. The coefficient for per capita GDP is negative, and so is the coefficient for the per capita GDP growth rate; both these findings align well with previous results. The other variables that are typically included do not seem to have any statistically observable impact on the occurrence of banking crises in the high-income sample.

\section{INSERT TABLE 2}

When examining the estimation of the same model with fixed effects, table 2 column 2 , none of the variables has a statically significant coefficient associated with it. This non-result is less surprising than may be expected since this is a first attempt to estimate a similar model for high-income countries separately - as for high income countries almost all of the banking crises are from the most recent global financial crisis (and this is a first attempt to use this most recent data). As there is little variability in the high-income country sample, 
we are unable to include variables measuring the history of currency crises and the de facto exchange rate regime.

For the middle-income country sample (1274 observations and 74 countries), the model without country-effects, table 2 column 3, obtained more statistically significant results, though the predictive power of the model appears to be very limited with a very low pseudo $\mathrm{R}^{2}$. All the variables we include in our benchmark specification, based on previous research, are statistically different from zero, except for the Chinn-Ito capital account openness index. As was the case for the high-income country sample, the banking history coefficient is positive and significant (though about half the size as for the high-income sample).${ }^{11}$ In the middle-income sample, we are also able to include a history-of-currencycrises variable, and it is also statistically significant (and half as large as the banking crisis coefficient). The GDP variables (in levels and growth rates) are similarly significant, while the coefficient for the GDP growth variable is smaller. As expected, the hyperinflation binary indicator is positive and significant. The banking liquidity and credit growth variables are both statistically significant - with higher banking liquidity decreasing the likelihood of a banking crisis while a pre-crisis credit expansion increasing it. ${ }^{12}$

When we add fixed-country-effects to this specification, table 2 column 4 , the variables that are significantly less time varying (banking history, the exchange rate regime, the hyperinflation indicator) all lose their statistical significance, as does the GDP growth rate variable. The per capita GDP coefficient retains its size and statistical significance. Interestingly, the Chinn-Ito measure is now negative and statistically significant - offering some evidence that, in middle-income countries, increasing capital account openness decreases the likelihood of a banking crisis. ${ }^{13}$ More difficult to interpret are the results for bank liquidity. The coefficient is now positive and significant (opposite sign than when no fixed-effects are included). Since this variable is less time-variant, it is unclear how we should interpret this result. The credit expansion coefficient retains its sign and significance.

\footnotetext{
${ }^{11}$ We are aware, of course, of the conventional wisdom that suggests that there may be cases of countries where it is widely believed that a deep crisis caused changes that reduced exposure to future crises; Chile and Israel in the 1980s or Sweden in the 1990s are all frequently mentioned. Our empirical results imply that these cases appear to be the exception, and not the rule.

${ }^{12}$ The banking asset variables have the same sign as in the high income sample.

${ }^{13}$ Glick et al. (2006) find similar evidence for the occurrence of currency crises.
} 
Since one of the contributions of this paper is to include the most recent data from the post-2008 Global Financial Crisis (henceforth GFC), we are interested in examining whether this most recent wave of crises is different from the previous 30 years of crisis history. We estimate the full country sample only for the most recent years of the global crisis, 20082010 (table 2 column 5); the model appears to provide strong predictive power, with a pseudo $R^{2}$ of 0.72 . The banking-history variable is positive and significant, as with the longer time period sample, but with a larger coefficient. Same is true for the de facto exchange rate regime index, and our measure of credit expansion. Other coefficients are no longer statistically significant.

\subsection{Robustness for model I}

The 1980s were characterized by banking crises in the debt-ridden countries of Latin America, but since the 1990s (and thereafter) we have been observing a different type of banking crises that are not necessarily connected to sovereign debt crises. In order to examine this 1980s-uniqueness hypothesis, we re-estimate our models using only the 19912010 data; but find that results are virtually identical. ${ }^{14}$

We also examined whether the (robust) negative effect of credit expansions may also be related to the degree of liquidity in the banking system, by including the interaction of the two variables in our benchmark specifications. The product of the two variables is in almost all cases insignificant and the coefficients on the credit expansions and the banking liquidity variables do not change substantially.

\subsection{Model II - cross section of banking crises observations}

The second part of our examination of banking crises is an investigation of the determinants of their magnitude. Unlike the first part, in which we use a binary measure of occurrence, an investigation into the depth of banking crises first has to determine how to measure the severity of a banking crisis. ${ }^{15}$ In the newest version of the banking crisis dataset (Laeven and Valencia, 2012), the authors also include three variables which may be

\footnotetext{
${ }^{14}$ We lose about 300 observations from our sample, but, qualitatively and quantitatively, the results are very similar.

${ }^{15}$ Most research on banking crises focuses on event indicators, either taken from earlier versions of the Laeven and Valencia dataset we use or its earlier incarnations collected at the International Monetary Fund.
} 
interpreted as alternative measures of the depth of the crisis. These are: the output loss measured as deviations of GDP from a calculated trend; the fiscal costs (measured as \% of GDP); and the peak non-performing loan (NPL) level reached (measured as \% of total loans). We thus estimate the following model:

$$
D E P T H_{i t}=\alpha+\beta X_{i t-1}+\delta B K C_{i t}^{H I S T}+\gamma C C_{i t}^{H I S T}
$$

Composing an output loss measure for banking crises (the first proxy for DEPTH) involves deciding on what constitutes the trend (the counterfactual) and determining the end of the crisis. ${ }^{16}$ We use the Laeven and Valencia data for this measure since they employ the standard IMF approach to this measurement (see appendix). The fiscal costs (the second proxy) are the bank restructuring costs defined as gross fiscal expenditures directed to the restructuring of the financial sector (e.g., recapitalization costs). The dataset includes both the gross fiscal costs and the net costs (costs minus whatever the government managed to 'claw' back in the five years following the onset of the crisis). We are interested in the depth of the crisis at the time it happens, and we consequently focus on the gross fiscal costs instead of net costs; net costs are also greatly affected by further development and the government's policy choices in the crisis aftermath. The NPL measure (the third proxy for DEPTH) includes the peak measure of NPLs during the five years since the crisis onset; in cases where less than five years of post-onset data is available, the observed peak is recorded.

The average fiscal costs of the crises in our sample is 12.2 (\% of GDP) while the costliest crisis by this measure costs the government 56.8 (\% of GDP) - this was Indonesia during the 1997-8 Asian Crisis. The average peak amount of non-performing loans is 28.6 (\% of loans in banking sector balance sheets) while the crisis with the highest NPL was estimated at $90 \%$ São Tomé \& Príncipe in 1992. The variance of the output loss measure is significantly higher, with the average loss estimated to be $30.1 \%$ of GDP; but in some instances no output loss is recorded and in others the loss is much higher. The country experiencing the costliest crisis, in terms of the downturn in economic activity, is Kuwait in 1982, but several other crises have an output loss that surpasses $100 \%$ of GDP - most notably Thailand during the Asian crisis of 1997-8 and Ireland during the recent global financial crisis.

\footnotetext{
${ }^{16}$ For discussion of various alternative measures of output loss associated in the context of financial crises see Hutchison et al. (2010).
} 
Surprisingly, the correlation between these measures of the magnitude of the banking crises is low (see table 3). The fiscal measure is positively correlated with the two other measures (NPL and output loss), albeit moderately at 0.33-0.38. The NPL measure, however, has no statistically observable correlation with the output loss measure. It appears that all three measures are recording a different aspect of the depth of the crisis, and are not very closely related to each other.

INSERT TABLE 3

For our control variables $X_{i t-1}$, we rely on Hutchison et al. (2010) that investigated the depth of other types of financial crises (in particular sudden stops in capital inflows), and Angkinand (2009) that focused on banking distress. Since the number of observations is limited to those banking crises for which data is available, we only include variables for which we could find sufficient coverage. In particular, for the full set of 138 banking crisis episodes described in the dataset, we only include those variables for which we have data for at least 100 observations. These variables include: monetary expansion during the crisis episode $^{17}$, IMF program intervention during the crisis, pre-crisis credit boom, average precrisis GDP growth rate, pre-crisis exchange rate regime (de facto), pre-crisis current account balance, pre-crisis inflation, and the pre-crisis degree of capital account openness (Chinn-Ito index).

Table 4 includes descriptive statistics for the independent variables in our crosssectional model. Most important is the observation that about $20 \%$ of the banking crises in our dataset are following a crisis that occurred in the decade preceding it. $35 \%$ of the banking crises were preceded by a credit boom, and 38\% ended up participating in an IMF program (typically short-term bailout programs). The average pre crisis current account deficit was quite large (3.7\% of GDP) while the average pre crisis GDP growth was low (0.2\%). Since this is a cross-sectional model, rather than a panel like the model of sections 3.1-3.3, we estimate the model with a standard ordinary least squares routine. INSERT TABLE 4

\subsection{Results and robustness for model II}

\footnotetext{
${ }^{17}$ Monetary expansion is computed as the change in the monetary base between its peak during the crisis and its level one year prior to the crisis (measured in percent of GDP).
} 
We estimate the model using the three alternative proxies for the severity of the crisis (NPL, output loss, and fiscal cost). Table 5 includes our regression results for the crosssectional model; columns 1-3 includes the full sample of banking crises (1980-2010) while columns 4-6 only include the banking crises associated with the GFC years (2008-2010). Table 5 column 1 estimates the determinants of the severity of the crises measured by the amount of non-performing loans in the banking system at the height of the crisis. We find that IMF intervention is associated with deeper crises (but of course IMF program intervention is not exogenous to the depth of the crisis). Higher GDP growth before the crisis is associated with fewer non-performing loans and capital account openness appears to reduce the amount of NPLs accumulating in the banking system. When estimating the depth of the crisis using the other two alternative definitions (table 5 columns 2-3), the results are broadly similar, with significant coefficients retaining their sign. The IMF variable loses its statistical significance when the output loss proxy is used, while the GDP growth measure loses its significance when the fiscal costs are used as a measure for the depth of the crisis. Given the small sample (55-70 observations); it may be less surprising that many of the included variables are statistically insignificant, though the explanatory power of the model (the $\mathrm{R}^{2}$ is between 0.22 to 0.40 ) is not insubstantial.

INSERT TABLE 5

We then progress to examine only the most recent banking systemic failures that are associated with the GFC. We find, in table 5 columns 4-6, that the broad outline of our results is maintained. The model is still only moderately successful. For NPLs, the results regarding the capital account openness are similar, while the results for the same variable, but for the output loss depth indicator on the LHS, are the opposite (and significant). It seems that higher capital account openness (de jure) is associated with lower levels of NPLS and higher levels of economic disruptions, as measured by forgone output. For the fiscal cost proxy of the crisis, the only significant (and positive) coefficient is the IMF indicator. We also attempted to examine whether the history of previous exposure of the banking sector to systemic crisis episodes seem to matter for the depth of the experienced crisis. We find no evidence to that effect; i.e., an indicator variable that denotes the occurrence of previous crises is always statistically insignificant (and negative). An accounting of the exact nature in which previous events cast a shadow into the future in financial markets remains, apparently, an open question in this case. 


\section{Data, Models, and Results - History and Saving Behaviour}

Our focus in this paper is the hypothesis that the burden of history matters for the macro-economy through the changed incentives at all levels of decision-making. We started with the intuition that countries that experienced previous banking crises will tend to be more cautious and experience fewer crises thereafter. We found the opposite: countries that have already experienced one banking crisis generally have a higher likelihood of experiencing another one; while the depth of the crisis does not appear to be affected by the previous historical experience with such events.

We next ask whether the same incentives are observable at the household level. Specifically, we ask whether the history of past economic contractions affects aggregate saving behaviour. Does income history matter?

The theory on the ways households deal with adverse income shocks does not lead to clear-cut predictions. Clearly, the main issue is whether previous income shocks had any impact on the households' perceptions of future uncertainty; an income shock that occurred a few decades ago is only important in that it might affect both the degree of risk averseness and decision maker's awareness of the possibility of future shocks. The literature on uncertainty and saving behavior is extensive, with early contributions by, for example, Levhari and Srinivasan (1969) and Sandmo (1970) - this, however, remains an empirically open question, and our contribution is purely empirical. ${ }^{18}$

Previous empirical research on the determinants of saving behavior focuses almost exclusively on country-specific data at the household level. ${ }^{19}$ Given our interest in the importance of aggregate country-level historical experiences and the way market participants adjust to them, our investigation has to be pursued using country-wide data. Recent papers most similar to ours in their empirical approach and specifications are Loayza et al. (2000) and Kinugasa and Mason (2007), though the latter's interest is mostly the demographic determinants of national saving. Loayza et al. (2000) use a panel dataset of

\footnotetext{
${ }^{18}$ See Browning and Lusardi (1996) for overview of the mirco theories and empirical regularities of household savings.

${ }^{19}$ The literature on the determinants of saving behaviour for households is much too extensive for us to discuss herein. Some projects examine aggregate macro-economic data at the local level within a country (e.g., Horioka and Wan, 2007, for an investigation of Chinese saving rates at the provincial level).
} 
saving rates for 1965-1994 and a very large sample of countries to estimate their determinants. Like our work, they pursue a reduced-form approach that attempts to identify broad regularities in the data rather than is wedded to a specific structural theory of saving. The theoretical literature, as well as the micro-empirical literature, is not cohesive enough to suggest a specific structural specification that would be empirically preferable.

We hypothesize that past large and adverse income shocks are empirically important in determining current saving behaviour. We examine this by constructing an index that measures the past exposure to 'income catastrophes' across the generations and examine whether this index is correlated with domestic saving. ${ }^{20}{ }^{21}$ We use data on income catastrophes going back to 1900 and saving and demographic details for the set of high- and middle-income countries for which this data is available.

\subsection{The Data}

In order to examine the possibility that the historical experience of income shocks affect present behaviour we need to construct an 'exposure to income catastrophes' index (henceforth EIC index) for every country and time observation in our dataset. The EIC index is essentially constructed from country-wide demographic data on the size of each cohort and the history of each cohort's exposure to catastrophic recessions since birth. Since the EIC index does not change much every year (neither demographics nor the historical record changes that rapidly), we construct our dataset in 5 year gaps: since saving data is typically available reliably only from the 1980s, we calculate the index for 5 observations per country (for the years 1985, 1990, 1995, 2000, 2005). We construct five alternatives of our EIC index. For demographic cohort-size data we use the World Bank's World Development Indicators

\footnotetext{
${ }^{20}$ We are not aware of any investigation of this question. Two papers have investigated the longterm impact of shocks on household behaviour using microeconomic datasets. Malmendier and Nagel (2011) examined the impact of exposure to stock-market return history on household investment risk-taking in the U.S., while Malmendier et al. (2011) investigated the impact of the Great Depression on the behaviour of company CEOs who grew up during that period.

${ }^{21}$ Schrooten and Stephan (2005) observe that saving rates increased significantly in the 1990s in the transition countries, following a few years of dramatic economic decline (and declining saving rates). While they examine different reasons for that, our hypothesis seems consistent with this observation. Households increased their saving after they were exposed to significant negative economic shocks. Similarly, Mody et al. (2012) observation of a large increase in saving following the 2008 global financial crisis, and their examination of its dependence on labour market uncertainty, is also consistent with our premise.
} 
while for data on catastrophic income shocks since 1900 we use the data from Barro and Ursua (2011).

\subsubsection{The 4 alternative EIC indices}

In order to examine the robustness of our results, and since there is no precedent to this measure, we use four different ways to construct our EIC index: For the benchmark index, the percent of population for each cohort is multiplied by the average of the past magnitude of catastrophic recessions weighted linearly according to how long ago they occurred. As an example, the equation below describes how we calculate the index for a country for the year 2005 using demographic cohort size as share of the national population $\left(d^{t}\right)$, the size of the reduction in per capita income for each catastrophic income shock in the historical record $\left(c_{s}\right)$, and the weights $\left(w_{t}\right)$ associated with each historical exposure. These weights are calculated according to the age of each cohort so that the weights are declining linearly and the weight at birth is zero. ${ }^{22}$ This index, as are the alternatives described below, is therefore higher as more of the population was exposed to larger or more recent crises.

$$
\operatorname{EIC} 1(2005)=\sum_{t=1925}^{1985} d^{t} \sum_{s=t}^{1985} 0.2(s-t) w_{t} c_{s}
$$

In a second version of this index, the benchmark index undergoes a log transformation.

$$
\operatorname{EIC} 2(2005)=2+\log \left[\sum_{t=1925}^{1985} d^{t} \sum_{s=t}^{1985} 0.2(s-t) w_{t} c_{s}\right]
$$

In the third alternative, we calculate the EIC Index by using only the cohorts aged 40-65 since these are the prime 'saving' cohorts.

$$
\operatorname{EIC} 3(2005)=2+\log \left[\sum_{t=1940}^{1965} d^{t} \sum_{s=t}^{1965} 0.2(s-t) w_{t} c_{s}\right]
$$

\footnotetext{
${ }^{22}$ Our choice to use linearly declining weights with zero weight at birth is based on the findings from Malmendier and Nagel (2011).
} 
Finally, our fourth alternative EIC index is calculated by assuming a non-linearity of the income catastrophe's impact (i.e., we use convex and concave functions of the measured per capita income decline during the recession). ${ }^{23}$

$$
\begin{aligned}
& \operatorname{EIC4}(2005)=2+\log \left[\sum_{t=1925}^{1985} d^{t} \sum_{s=t}^{1985} 0.2(s-t) w_{t}\left(c_{s}\right)^{1 / 2}\right] \\
& \operatorname{EIC5}(2005)=2+\log \left[\sum_{t=1925}^{1985} d^{t} \sum_{s=t}^{1985} 0.2(s-t) w_{t}\left(c_{s}\right)^{2}\right]
\end{aligned}
$$

We have data for 40 countries: the only binding constraint on data availability is information about past recessions going back to 1900 - we use all the data available in the Barro-Ursua dataset). Given a few missing observations, we end up with about 90 observations each for the high- and middle-income samples. The indices 2-4 are highly correlated between them (0.93-0.97) while index1 is only slightly less correlated with the rest (0.81-0.88); the regression results described below are virtually identical for all four alternative indices.

\subsubsection{Other Data}

In the regressions described below, we estimate the determinants of saving rates across countries.

$$
S A V_{i t}=\alpha_{i t}+\beta X_{i t-1}+\delta E I C n_{i t}
$$

As our dependent variable, we have the national saving rate. Our main independent variable of interest is the EIC described in the previous section. Kinugasa and Mason (2007) also estimated the determinants of saving rates across countries, and we use their list of controls $\left(X_{i t-1}\right)$ in determining the appropriate RHS variables in our regression specifications. We use: average GDP growth in previous five years period; the real interest rate (average for previous five years); labour participation rate (average for previous five

\footnotetext{
${ }^{23}$ Index 4 and 5 are concave and convex transformations of the crisis depth measure. For the concave transformation, we are hypothesizing that the measurable depth of the downturn is less important than the actual event occurring, and with the convex transformation we are examining whether especially catastrophic collapses in incomes have a more pronounced effect on saving behavior.
} 
years); and a proxy for institutional strength (we use the International Country Risk Guides political risk measure ${ }^{24}$ ).

\subsection{Descriptive Statistics and Regression Results}

\section{INSERT FIGURE 1}

We start by examining the EIC index for high-income countries; in figure 1 we present the EIC index (\#1) for the year 2005. Germany has the highest index as a result of its aging population and the very dramatic output contractions experienced in the 1920 s and the 1940s. Singapore, the country with the second highest index, has a historical record of very large fluctuations of incomes throughout the $20^{\text {th }}$ century. Singapore is also a clear outlier in terms of its saving rates (see figure 2) with saving rates ranging between $41-50 \%$ of GDP - a much higher rate than for any other developed country in our sample (whose range is 1134).

\section{INSERT FIGURE 2}

We hypothesized that countries with a higher EIC index will, ceteris paribus, save more; and indeed when we examine the statistical relationship between these two variables for the high-income sample we consistently find a positive relationship in both bi-variate and multi-variate specifications (e.g., table 6, column 1). However, these results are not robust to the exclusion of the one obvious outlier, Singapore. Once we exclude Singapore from the estimations, we find little robust evidence of connection between saving behavior and our historical index (results not presented for brevity); neither does this result remain when we include country-fixed-effects. We therefore focus only on middle-income countries in the discussion that follows and in the specifications we include (see Figures 3-4, and columns 36 in table 6).

\section{INSERT FIGURES 3 and 4}

Middle-income countries have a much higher EIC index than is typical for the highincome countries in our sample. In spite of their generally younger demographics, almost all

\footnotetext{
${ }^{24}$ The ICRG political risk index ranges from 1-100 with higher numbers signifying a less risky political environment. To simplify the analysis, we change the sign so that higher numbers register more political risk.
} 
middle-income countries have a higher EIC than Germany (which the highest in the high income group) - see figure 3. It is also quite apparent that saving rates for middle-income countries are both higher and more varied than for the high-income sample. In short, across income levels the correlations between the EIC and saving rates are not immediately obvious.

For middle-income countries, we estimate domestic saving (\% of GDP) on the LHS with both pooled-OLS and with fixed effects; results change as the EIC index does not vary much over time, so that inserting country fixed effects removes much of the cross-country differences in the index. As in the high-income sample, we prefer to be able to focus on the cross-country differences rather than only at the impact of the change in the index over time in each country. We estimate the OLS specifications with a White-heteroskedasticitycorrection assuming clustered standard errors by country.

\section{INSERT TABLE 6}

Our original hypothesis was that the index should be positively correlated with the saving rate, as a higher index signifies greater exposure to more significant adverse income shocks. However, in the initial specification, presented in column 3, the coefficient of the EIC index is statistically insignificant (indistinguishable from zero) but negative; it is negative and significant when fixed-effects are included (column 4). For the other independent variables in our estimation: GDP growth is statistically significant and positive; real interest rate is negative and statistically significant, labour participation and the institutional proxy are positive and statistically significant. These results closely match our priors and previous research (Kinugasa and Mason, 2007). The $\mathrm{R}^{2}$ for the empirical model is high; 0.52 for control variables, 0.92 if adding fixed effects ( 0.49 and 0.90 , respectively, when controlling for the number of independent variables included in the model).

This result of a negative relationship between the exposure index and the saving rate is counter-intuitive, and suggests that, if it is indeed robust, originates from differences across countries that make some countries more likely to experience income volatility and have lower saving rates. We hypothesize that the difference lies in the institutional structure of the economies compared. In countries with a high level of political risk people will worry more about a repetition of the income catastrophes, while countries that end up enjoying an improved institutional framework, with lower political risk, the impact of past events is muter. 
We find that in countries with much political risk the past experience does seem to matter; so that countries with more people who were exposed to larger disasters more recently will tend to save more. This is, however, not the case for countries with more stable political systems.

\section{Conclusions}

We close the paper with a discussion of open issues needing further research, and possible interpretations. Establishing the root causes of our failure to detect a learning process from past banking crises is well beyond the scope of this paper, but is needed to provide a proper interpretation. One possible explanation is that regulators and policymakers are learning, but at a speed that does not catch up with the dynamic evolution of modern banking. While it is easier to deal with deficiencies revealed by past crises, it may be hard to identifying new vulnerabilities propagated by rapidly changing financial technologies and instruments and the entry of new players. Consequently, the regulator frequently is preparing to prevent the last crisis, and not the future one, as the contours of the future vulnerabilities are fuzzy. In these circumstances, a possible remedy may call for slowing down the diffusion of financial innovations, treating them as risky until proven otherwise. Instead of presuming that 'this time is different', the regulator should presume that the next crisis will come in a new shape and form. This cautious attitude may call for much more stringent leverage and reserve ratios, and blocking the introduction of financial innovations that may be 'too clever by half' for users and for regulators.

A more troublesome interpretation is the possibility that too much political clout upheld by the financial system may cut the resources available to the regulator, and his ability to impose policies that are deemed too costly for and by the financial system. This concern arises especially in the context of the 'too big to fail' doctrine, where the private rents associated with excessive risk taking by the banking systems require adversarial relationships between the regulators and the private banking system. In these circumstances, policies aiming at curtailing the political clout of big financial institutions may help. Yet, these policies may be hard to implement in countries dominated by few large financial players with cozy associations with the political process and with large conglomerates. Chances are that countries differ in the relative importance of these 
considerations. Identifying the weight of the causes accounting for the lack of learning from banking crises remains an important research agenda.

Similarly, our mixed findings about the impact of history on savings suggest the need to look more closely at the political economy and the functioning and credibility of institutions. The Ricardian equivalence hypothesis suggests that the patterns of private savings are impacted by the degree to which the public sector helps or hinders dealing with turbulent income. One expects that in countries where the public sector has been providing effective social safety net, and is not the root cause of instability, the impact of history on private saving is muted. This is probably in line with our findings that only for middle income countries with much political risk does past experience seem to matter; so that such countries with more people who were exposed to larger disasters more recently will tend to save more.

Better understanding of these forces may require better understanding of patterns of public savings, and the expectations regarding the viability and credibility of public safety nets. Our findings also raise important questions about the unintended consequences of policies that aim to assist households in dealing with adverse macroeconomic environments. For countries with higher degrees of political uncertainty, saving behavior may provide a pro-cyclical force that may create higher income volatility. All of these dynamics are bound to play important roles in the coming decades given the unprecedented nature of the 20082010 GFC.

\section{References}

Alesina Alberto and Allan Drazen (1991) "Why are Stabilizations Delayed?" American Economic Review 81, 5: 1170-1188.

Angkinand, Apanard P., 2009. "Banking regulation and the output cost of banking crises," Journal of International Financial Markets, Institutions and Money, 19(2), 240-257.

Arteta, C., Eichengreen, B., 2002. Banking crises in emerging markets: presumptions and evidence. In: Blejer, M., Skreb, M. (Eds.), Financial Policies in Emerging Markets. MIT Press, Cambridge, MA.

Barro, Robert J., José F. Ursua, 2011. Rare Macroeconomic Disasters. NBER Working Paper No. 17328. 
Beck, Thortsen and Asli Demirgüç-Kunt, 2009. Financial Institutions and Markets Across Countries and over Time: Data and Analysis. World Bank Policy Research Working Paper No. 4943. [update posted at worldbank.org].

Berkmen, S. Pelin, Gaston Gelos, Robert Rennhack, James P. Walsh, 2012. The global financial crisis: Explaining cross-country differences in the output impact. Journal of International Money and Finance, 31, 1, 42-59.

Bongini, P., Claessens, S., Ferri, G., 2001. The political economy of distress in East Asian financial institutions. Journal of Financial Services Research 19 (1), 5-25.

Browning M., A. Lusardi ,1996. Household Saving: Micro Theories and Micro Facts. Journal of Economic Literature, 34(4), 1797-1855.

Cecchetti, Stephen, Michael King and James Yetman, 2012. Weathering the financial crisis: policy or luck? BIS working paper \#351.

Chinn, Menzie and Hiro Ito, 2006. What matters for financial development? Capital controls, institutions, and interactions. Journal of Development Economics 82, 163-192.

Demirgüç-Kunt, A., Detragiache, E., 1998. The determinants of banking crises in developing and developed countries. IMF Staff Papers 45, 81-109.

Demirgüç-Kunt, A., Detragiache, E., 2005. "Cross-Country Empirical Studies of Systemic Bank Distress: A Survey. IMF Working Papers 05/96.

Duttagupta, Rupa and Cashin, Paul, (2011), Anatomy of banking crises in developing and emerging market countries, Journal of International Money and Finance, 30(2), p. 354-376.

Edwards, Sebastian, 1996. Why are Latin America's savings rates so low? An international comparative analysis. Journal of Development Economics, 51, 5-44.

Glick, R., Hutchison, M., 2001. Banking and currency crises: how common are twins?. In: Glick, R., Moreno, R., Spiegel, M. (Eds.), Financial Crises in Emerging Markets. Cambridge UP, Cambridge, UK.

Glick, R., X. Guo and M. Hutchison, 2006. Currency Crises, Capital Account Liberalization, and Selection Bias. Review of Economics and Statistics, 88(4): 698-714.

Greene, William, 2012. LIMDEP Version 10 Econometric Modeling Guide. Econometric Software, Inc.

Hellmann, F. Thomas, Kevin C. Murdock and Joseph E. Stiglitz (2000) "Liberalization, Moral Hazard in Banking, and Prudential Regulation: Are Capital Requirements Enough?" American Economic Review 90, 1: 147-165.

Horioka, Charles Yuji, Junmin Wan, 2007. The Determinants of Household Saving in China: A Dynamic Panel Analysis of Provincial Data. Journal of Money, Credit and Banking, 39(8), 2077-2096. 
Hutchison, Michael, Noy, Ilan, 2005. How Bad Are Twins? Output Costs of Currency and Banking Crises. Journal of Money, Credit and Banking, 37(4), 725-752.

Hutchison, Michael, Noy, Ilan and Wang, Lidan, 2010. Fiscal and Monetary Policies and the Cost of Sudden Stops. Journal of International Money and Finance, 29, 973-987.

Iltzeki, Ethoan, Carmen, Reinhart, and Kenneth Rogoff, 2011. The Country Chronologies and Background Material to Exchange Rate Arrangements in the 21st Century: Which Anchor Will Hold?, manuscript.

Joyce, Joseph, 2011. "Financial Globalization and Banking Crises in Emerging Markets", Open Economies Review, vol. 22 no. 5.

Kaminsky, G., Reinhart, C., 1999. The twin crises: the causes of banking and balance-ofpayments problems. American Economic Review 89 (3), 473-500.

Laeven, Luc A. and Valencia, Fabian V., (2012). Systemic Banking Crises Database: An Update. IMF working paper 12/163.

Levhari, D. and T. N. Srinivasan, 1969. Optimal Savings Under Uncertainty. Review of Economic Studies 36(2), pp. 153-163.

Loayza, Norman, Klaus Schmidt-Hebbel, Luis Servén, 2000. What Drives Private Saving Across the World? Review of Economics and Statistics, 82(2), 165-181.

Malmendier, Ulrike, and S. Nagel, 2011. Depression Babies: Do Macroeconomic Experiences Affect Risk-Taking? Quarterly Journal of Economics 126(1), 373-416.

Malmendier, Ulrike, G. Tate and J. Yan, 2011. Overconfidence and Early-life Experiences: The Effect of Managerial Traits on Corporate Financial Policies. Journal of Finance, 66(5).

Mason, Andrew, And Tomoko Kinugasa, 2007. Why Countries Become Wealthy: The Effects of Adult Longevity on Saving. World Development 35(1), 1-23.

Masson, Paul R., Tamim Bayoumi and Hossein Samiei, 1998. International evidence on the determinants of private saving. World Bank Economic Review, 12(3), 483-501.

Mitra, Devashish (1999) "Endogenous Lobby Formation and Endogenous Protection: A LongRun Model of Trade Policy Determination" American Economic Review. 89, 5: 1116-1134.

Mody, Ashoka, Franziska Ohnsorge, Damiano Sandri, 2012. Precautionary Savings in the Great Recession. IMF Economic Review 60(1), 114-138.

Noy, I., 2004. Financial Liberalization, Prudential Supervision and the Onset of Banking Crises - Empirical Findings." Emerging Markets Review 5(3), 341-359.

Perotti C. Enrico and Kathryn E. Spier (1993) "Capital Structure as a Bargaining Tool: The Role of Leverage in Contract Renegotiation," American Economic Review, 83, 5: 1131-1141. 
Sandmo, A., 1970. The Effect of Uncertainty on Saving Decisions. Review of Economic Studies, 37(3), 353-360.

Serwa, Dobromił, 2010. Larger crises cost more: Impact of banking sector instability on output growth. Journal of International Money and Finance, 29, 8, 1463-1481.

Schaeck, Klaus \& Martin Cihak \& Simon Wolfe, 2009. "Are Competitive Banking Systems More Stable?" Journal of Money, Credit and Banking, 41(4), 711-734.

Schrooten, Mechthild and Sabine Stephan, 2005. Private savings and transition: Dynamic panel data evidence from accession Countries. Economics of Transition, 13 (2), 287-309.

von Hagen, Jürgen \& Tai-Kuang Ho, 2007. "Money Market Pressure and the Determinants of Banking Crises," Journal of Money, Credit and Banking, 39(5), 1037-1066.

Yeyati, Eduardo Levy \& Micco, Alejandro, 2007. "Concentration and foreign penetration in Latin American banking sectors: Impact on competition and risk," Journal of Banking and Finance, 31(6), 1633-1647. 
Figure 1 - EIC Index for High Income Countries (2005)

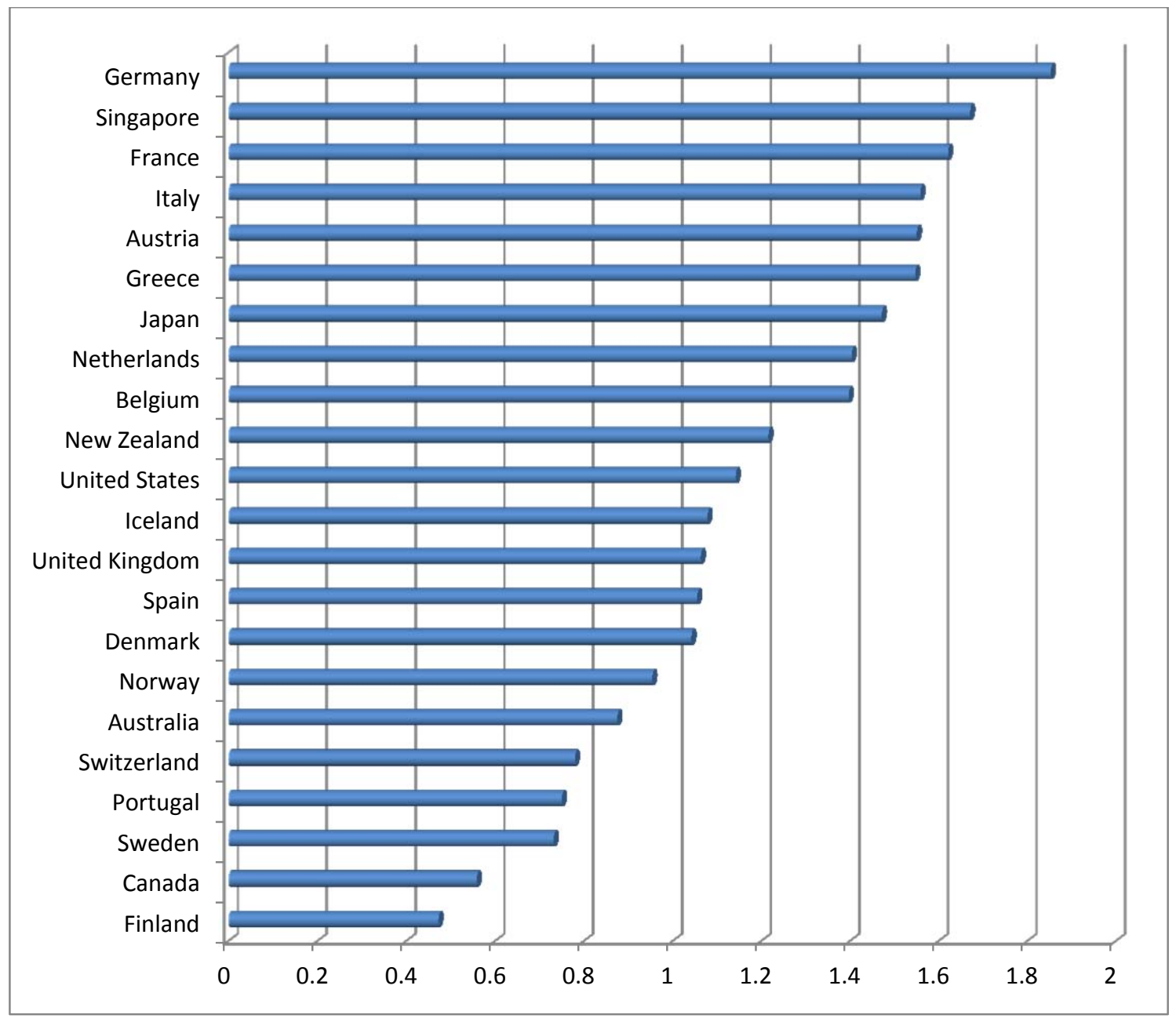


Figure 2 - Saving/EIC for High Income Countries

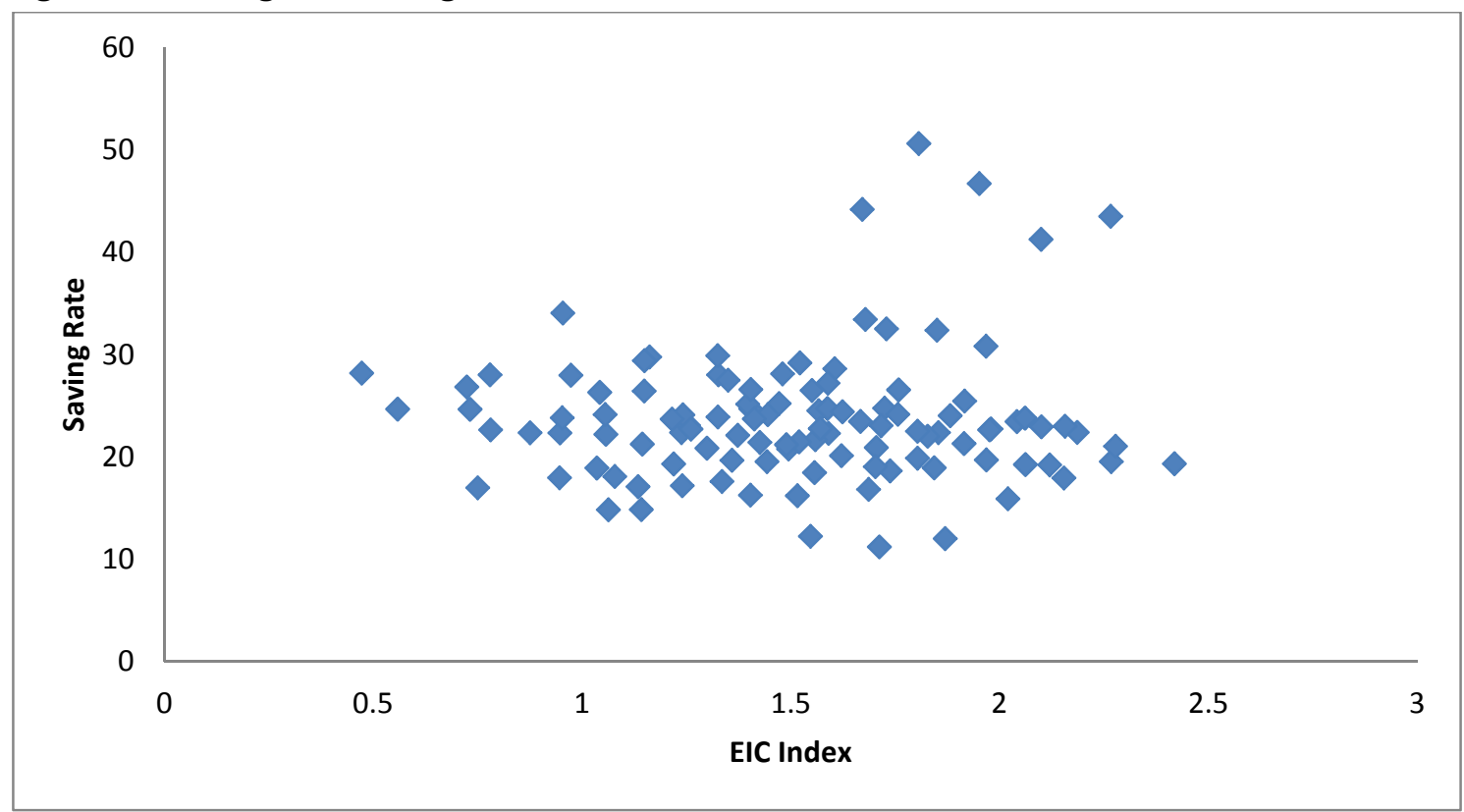


Figure 3 - EIC Index for Middle Income Countries (2005)

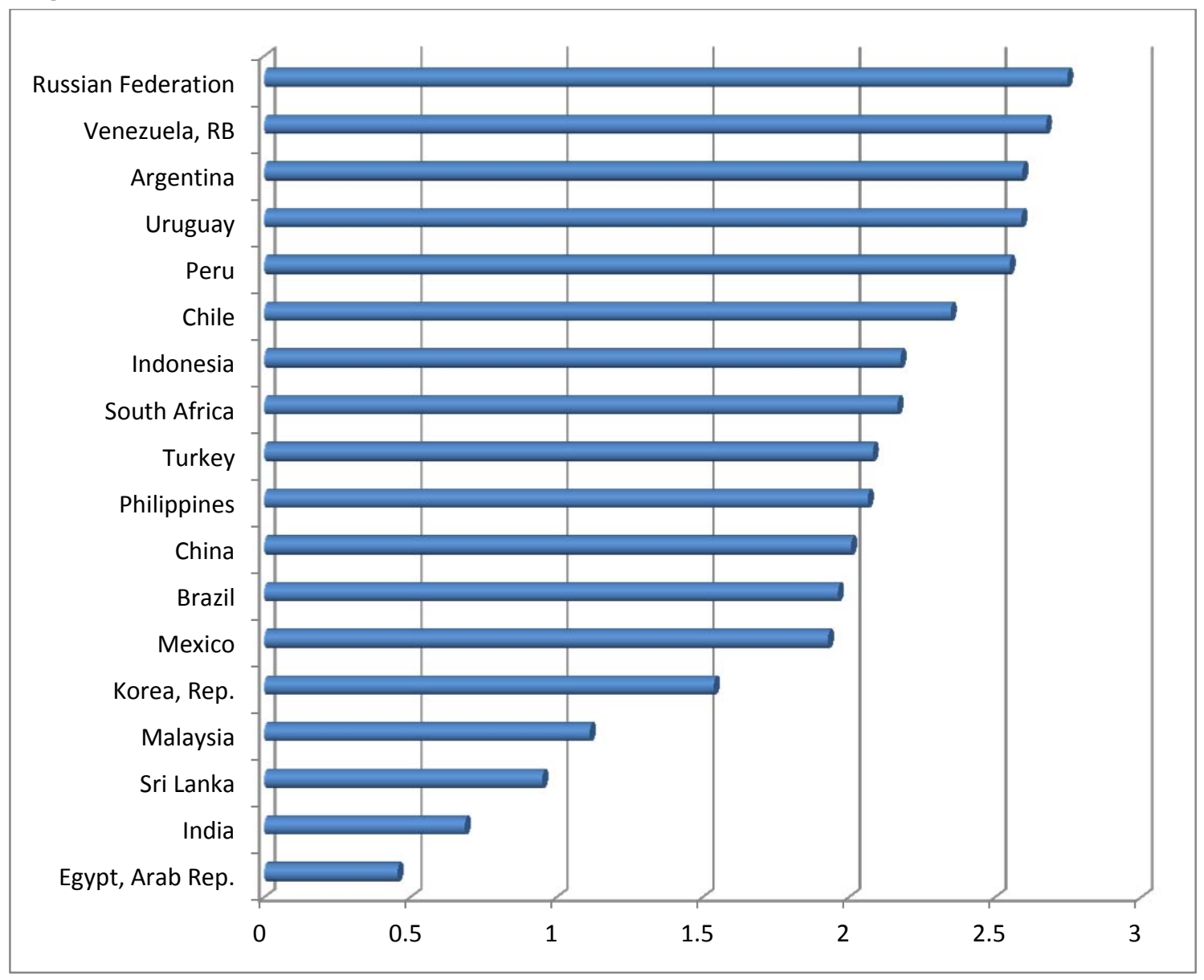


Figure 4 - Saving/EIC for Middle Income Countries

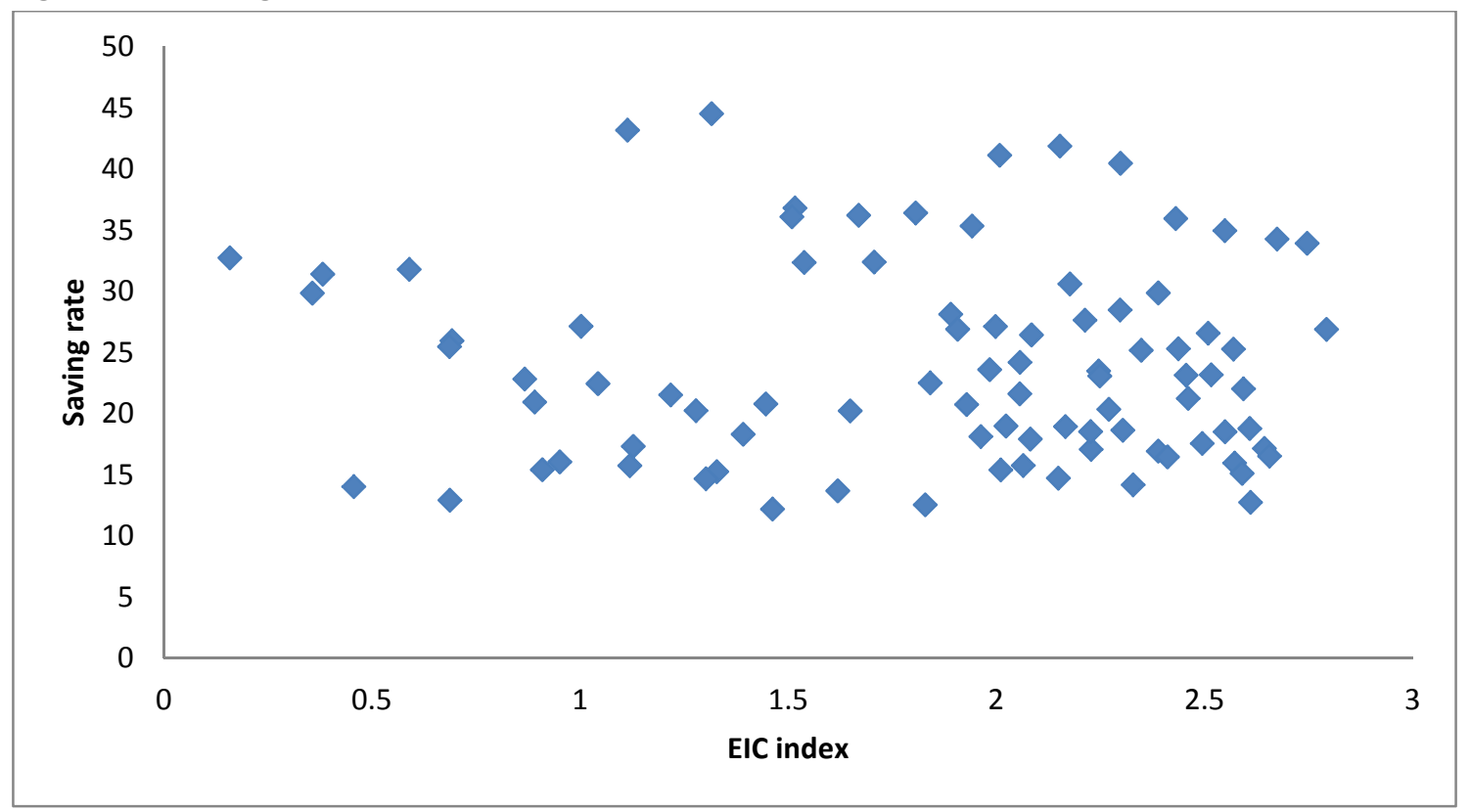


Table 1 - Descriptive Statistics for Panel Dataset

\begin{tabular}{|c|c|c|c|}
\hline Explanatory Variables & GFC Sample & High Income & Middle Income \\
\hline \multirow{3}{*}{ Banking crises onset } & 0.049 & 0.029 & 0.028 \\
\hline & $(0.217)$ & $(0.167)$ & $(0.166)$ \\
\hline & [486] & [806] & [1943] \\
\hline \multirow{3}{*}{ Banking crises history } & 0.200 & 0.156 & 0.296 \\
\hline & $(0.4)$ & $(0.363)$ & $(0.457)$ \\
\hline & [486] & [806] & [1943] \\
\hline \multirow{3}{*}{ Currency crises history } & 0.041 & 0.035 & 0.124 \\
\hline & (0.199) & $(0.183)$ & (0.329) \\
\hline & [486] & [806] & [1943] \\
\hline \multirow{3}{*}{ Duration of banking crises } & 0.150 & 0.092 & 0.086 \\
\hline & $(0.358)$ & $(0.289)$ & $(0.281)$ \\
\hline & [486] & [806] & [1943] \\
\hline \multirow{3}{*}{ Credit (share of GDP) } & 0.582 & 0.883 & 0.346 \\
\hline & $(0.515)$ & $(0.429)$ & $(0.232)$ \\
\hline & {$[252]$} & {$[700]$} & [1525] \\
\hline \multirow{3}{*}{ GDP per capita (in constant \$) } & 7071.960 & 22924.200 & 3379.760 \\
\hline & $(10682.5)$ & (7941.38) & $(2290.99)$ \\
\hline & [467] & [806] & [1943] \\
\hline \multirow{3}{*}{ Real GDP per capita growth rate } & 1.488 & 1.753 & 2.269 \\
\hline & $(4.463)$ & (3.102) & $(5.776)$ \\
\hline & [470] & [803] & [1921] \\
\hline \multirow{3}{*}{ Capital account openness } & 0.492 & 1.816 & -0.093 \\
\hline & $(1.644)$ & $(1.046)$ & $(1.462)$ \\
\hline & [467] & [714] & [1767] \\
\hline \multirow{3}{*}{ Exchange rate regime (de facto) } & 1.994 & 2.184 & 2.360 \\
\hline & $(1.069)$ & (1.117) & (1.361) \\
\hline & [473] & [783] & [1769] \\
\hline \multirow{3}{*}{ Hyperinflation (binary) } & 0.004 & 0.015 & 0.087 \\
\hline & $(0.064)$ & $(0.121)$ & $(0.282)$ \\
\hline & [486] & [806] & [1943] \\
\hline \multirow{3}{*}{ Credit (share of GDP) } & 0.664 & 1.037 & 0.441 \\
\hline & $(0.530)$ & $(0.451)$ & $(0.260)$ \\
\hline & [250] & [701] & [1536] \\
\hline
\end{tabular}

Note: The table includes the means, the (standard deviations), and the [number of observations]. 
Table 2 - Banking crises, Regression Results for Panel Model

\begin{tabular}{|c|c|c|c|c|c|}
\hline \multirow[b]{2}{*}{ Explanatory Variables } & \multicolumn{2}{|c|}{ High Income } & \multicolumn{2}{|c|}{ Middle Income } & \multirow{2}{*}{$\begin{array}{c}\text { GFC } \\
\text { No Fixed } \\
\text { Effects }\end{array}$} \\
\hline & $\begin{array}{l}\text { No Fixed } \\
\text { Effects }\end{array}$ & $\begin{array}{c}\text { Fixed } \\
\text { Effects }\end{array}$ & $\begin{array}{l}\text { No Fixed } \\
\text { Effects }\end{array}$ & $\begin{array}{l}\text { Fixed } \\
\text { Effects }\end{array}$ & \\
\hline Banking crises history & $\begin{array}{r}2.909 \\
(7.93)^{* * *}\end{array}$ & $\begin{array}{r}279.77 \\
(0.01)\end{array}$ & $\begin{array}{r}1.053 \\
(6.96)^{* * *}\end{array}$ & $\begin{array}{r}12.432 \\
(0.00)\end{array}$ & $\begin{array}{r}4.323 \\
(5.87)^{* * *}\end{array}$ \\
\hline Currency crises history & & & $\begin{array}{r}0.499 \\
(2.39)^{* *}\end{array}$ & $\begin{array}{r}0.643 \\
(1.69)^{*}\end{array}$ & \\
\hline Exchange rate regime $(\mathrm{t}-1)$ & & & $\begin{array}{r}-0.537 \\
(-7.83)^{* * *}\end{array}$ & $\begin{array}{l}-0.204 \\
(-1.43)\end{array}$ & $\begin{array}{r}-1.873 \\
(-4.71)^{* * *}\end{array}$ \\
\hline GDP per capita (t-1) & $\begin{array}{r}-0.000 \\
(-5.79)^{* * *}\end{array}$ & $\begin{array}{l}0.001 \\
(0.00)\end{array}$ & $\begin{array}{r}-0.000 \\
(-4.19)^{* * *}\end{array}$ & $\begin{array}{r}-0.001 \\
(-3.05)^{* * *}\end{array}$ & $\begin{array}{l}0.000 \\
(1.54)\end{array}$ \\
\hline GDP per c growth rate $(\mathrm{t}-1)$ & $\begin{array}{r}-0.260 \\
(-4.33)^{* * *}\end{array}$ & $\begin{array}{r}-6.00 \\
(0.00)\end{array}$ & $\begin{array}{r}-0.062 \\
(-3.83)^{* * *}\end{array}$ & $\begin{array}{l}0.022 \\
(0.55)\end{array}$ & $\begin{array}{l}-0.068 \\
(-1.03)\end{array}$ \\
\hline Hyperinflation (binary) (t-1) & & & $\begin{array}{r}0.721 \\
(2.47)^{* *}\end{array}$ & $\begin{array}{l}0.657 \\
(1.23)\end{array}$ & \\
\hline Credit (t-1) & $\begin{array}{l}-0.106 \\
(-0.40)\end{array}$ & $\begin{array}{r}404.363 \\
(0.01)\end{array}$ & $\begin{array}{r}-1.856 \\
(-5.57)^{* * *}\end{array}$ & $\begin{array}{r}8.825 \\
(4.29)^{* * *}\end{array}$ & $\begin{array}{l}-0.775 \\
(-0.79)\end{array}$ \\
\hline Credit growth (t-1) & $\begin{array}{l}0.666 \\
(0.42)\end{array}$ & $\begin{array}{r}215.188 \\
(0.00)\end{array}$ & $\begin{array}{r}8.860 \\
(4.55)^{* * *}\end{array}$ & $\begin{array}{r}20.904 \\
(4.66)^{* * *}\end{array}$ & $\begin{array}{r}8.169 \\
(1.67)^{*}\end{array}$ \\
\hline Capital account openness (t-1) & $\begin{array}{l}0.183 \\
(1.36)\end{array}$ & $\begin{array}{r}-16.687 \\
(0.00)\end{array}$ & $\begin{array}{l}-0.054 \\
(-0.96)\end{array}$ & $\begin{array}{r}-0.504 \\
(-3.25)^{* * *}\end{array}$ & $\begin{array}{l}-0.003 \\
(-0.24)\end{array}$ \\
\hline Psuedo $\mathrm{R}^{2}$ & 0.41 & & 0.29 & & 0.71 \\
\hline Observations & 597 & 597 & 1274 & 1274 & 224 \\
\hline
\end{tabular}

Note: The dependent (LHS) variable is a binary indicator denoting the onset of a banking crisis ( $0=$ no crisis). All columns were estimated with a Probit specification with the onset variable, country-year observations which were the continuation of an already noted crisis onset were excluded. Both models, including and excluding the fixed effects, were estimated in LIMDEP. The t-stats are denoted in parentheses with the standard statistical significance indicated at the 10,5 , and $1 \%$ levels by *,**, and ${ }^{* * *}$, respectively. 
Table 3 - Descriptive Statistics for Depth of Crisis Variables

\begin{tabular}{|lrrr|}
\hline \multicolumn{1}{|c}{ Explanatory Variables } & Mean & $\begin{array}{r}\text { Standard } \\
\text { Deviation }\end{array}$ & Cases \\
\hline Fiscal cost (\% of GDP) & 12.222 & 13.255 & 85 \\
Non-performing loans (NPL) & & & \\
(\% of assets in banking sector) & 28.629 & 21.497 & 104 \\
& & & \\
GDP loss (relative to trend, in \%) & 30.113 & 33.709 & 124 \\
\hline & & & \\
\hline Correlations & Fiscal cost & NPL & GDP loss \\
Fiscal cost & 1.000 & 0.333 & 0.379 \\
NPL & & 1.000 & -0.066 \\
GDP loss & & & 1.000 \\
\hline
\end{tabular}


Table 4 - Descriptive Statistics for Cross-section Dataset

\begin{tabular}{|lrrr|}
\hline Explanatory Variables & Mean & $\begin{array}{r}\text { Standard } \\
\text { Deviation }\end{array}$ & Cases \\
\hline Banking crisis history & 0.199 & 0.400 & 136 \\
Monetary expansion & 1.951 & 7.057 & 114 \\
IMF program & 0.382 & 0.488 & 136 \\
Credit boom & 0.350 & 0.479 & 120 \\
GDP growth (t-1) & 0.247 & 5.236 & 108 \\
Exchange rate regime (t-1) & 2.590 & 1.630 & 122 \\
Current account balance (\% of GDP) (t-1) & -3.740 & 10.085 & 124 \\
Inflation rate (t-1) & 171.201 & 915.631 & 114 \\
Capital account openness (t-1) & -0.026 & 1.561 & 121 \\
\hline
\end{tabular}


Table 5 - Banking Crises depth, Regression Results for Cross-section Model

\begin{tabular}{|c|c|c|c|c|c|c|}
\hline \multirow{2}{*}{$\begin{array}{l}\text { Explanatory Variables } \\
\text { Constant }\end{array}$} & \multicolumn{3}{|c|}{ Full Sample } & \multicolumn{3}{|c|}{ GFC Sample } \\
\hline & 18.324 & 22.185 & 7.180 & 32.791 & 2.264 & 10.672 \\
\hline & $(3.57)^{* * *}$ & $(2.46)^{* *}$ & $(1.45)$ & $(2.02)^{*}$ & $(0.07)$ & $(0.64)$ \\
\hline \multirow{2}{*}{ Monetary expansion } & -0.275 & 0.502 & -0.078 & -0.817 & -1.560 & 0.064 \\
\hline & $(-0.50)$ & $(0.54)$ & $(-0.19)$ & $(-0.74)$ & $(-0.66)$ & $(0.05)$ \\
\hline \multirow{2}{*}{ IMF } & 10.076 & 5.103 & 9.771 & -0.365 & 15.024 & 13.482 \\
\hline & $(2.47)^{* * *}$ & $(0.62)$ & $(2.55)^{* *}$ & $(-0.05)$ & (1.09) & $(1.92)^{*}$ \\
\hline \multirow{2}{*}{ Credit boom (t-1) } & 0.859 & 0.760 & 3.376 & -2.546 & 14.931 & 8.416 \\
\hline & $(-0.21)$ & $(0.09)$ & $(0.85)$ & $(-0.42)$ & $(1.18)$ & $(1.30)$ \\
\hline \multirow{2}{*}{ GDP growth (t-1) } & -1.436 & -4.160 & -0.557 & 0.722 & -5.316 & -3.038 \\
\hline & $(-2.21)^{* *}$ & $(-3.35)^{* * *}$ & $(-0.89)$ & $(0.23)$ & $(-0.82)$ & $(-0.92)$ \\
\hline \multirow{2}{*}{ Exchange rate regime $(\mathrm{t}-1)$} & 1.042 & -0.120 & 0.268 & 5.60 & 1.404 & 1.803 \\
\hline & $(0.61)$ & $(-0.04)$ & $(0.16)$ & $(1.18)$ & $(0.14)$ & $(0.35)$ \\
\hline Current account balance & -0.276 & 0.056 & 0.057 & -0.802 & -0.420 & 0.244 \\
\hline$(\mathrm{t}-1)$ & $(-0.91)$ & $(0.09)$ & $(0.22)$ & $(-1.69)$ & $(-0.45)$ & $(0.52)$ \\
\hline & -0.001 & 0.005 & -0.004 & -1.373 & -0.140 & -1.045 \\
\hline Inflation (t-1) & $(-0.75)$ & $(1.16)$ & $(-0.67)$ & $(-1.71)$ & $(-0.09)$ & $(-1.29)$ \\
\hline Capital account openness & -3.958 & 3.127 & -0.090 & -8.805 & 13.660 & -2.360 \\
\hline$(\mathrm{t}-1)$ & $(-2.70)^{* * *}$ & $(1.18)$ & $(-0.07)$ & $(-2.47)^{* *}$ & $(1.88)^{*}$ & $(-0.64)$ \\
\hline Observations & 62 & 70 & 55 & 20 & 21 & 21 \\
\hline Left hand side & NPL & LOSS & FISGDP & NPL & LOSS & FISGDP \\
\hline$R^{2}$ & 0.409 & 0.196 & 0.221 & 0.685 & 0.655 & 0.515 \\
\hline$\overline{R^{2}}$ & 0.319 & 0.091 & 0.086 & 0.456 & 0.426 & 0.191 \\
\hline
\end{tabular}

Note: The dependent (LHS) variable is banking crises depth: NPL - columns (1) and (4); Output loss columns (2) and (5); Fiscal cost - columns (3) and (6). Since the LHS variables are continuous, this crosssectional model was estimated with a Least Squares specification. Columns (4)-(6) include only the crises of the Global Financial Crisis (post 2007), while columns (1)-(3) include the complete sample including all crises for which the required information was available. The $t$-stats are denoted in parentheses with the standard statistical significance indicated at the 10,5 , and $1 \%$ levels by $*, * *$, and $* * *$, respectively. 
Table 6 - Regression Results for Saving Rates

\begin{tabular}{|c|c|c|c|c|c|c|}
\hline $\begin{array}{c}\text { Explanatory } \\
\text { Variables }\end{array}$ & $\begin{array}{c}\text { Developed } \\
\text { Countries } \\
\text { OLS } \\
\end{array}$ & $\begin{array}{c}\text { Developed } \\
\text { Countries } \\
\text { FE } \\
\end{array}$ & $\begin{array}{c}\text { Developing } \\
\text { Countries } \\
\text { OLS } \\
\end{array}$ & $\begin{array}{c}\text { Developing } \\
\text { Countries } \\
\text { FE } \\
\end{array}$ & $\begin{array}{c}\text { Developing } \\
\text { Countries } \\
\text { OLS } \\
\end{array}$ & $\begin{array}{c}\text { Developing } \\
\text { Countries } \\
\text { FE } \\
\end{array}$ \\
\hline Constant & $\begin{array}{r}-12.866 \\
(-1.57)\end{array}$ & & $\begin{array}{r}-17.273 \\
(-2.36)^{* *}\end{array}$ & & $\begin{array}{r}-42.836 \\
(-3.12)^{* * *}\end{array}$ & \\
\hline EIC index & $\begin{array}{r}3.438 \\
(2.31)^{* *}\end{array}$ & $\begin{array}{l}0.201 \\
(0.27)\end{array}$ & $\begin{array}{l}-0.591 \\
(-0.46)\end{array}$ & $\begin{array}{r}-5.522 \\
(-4.79)^{* * *}\end{array}$ & $\begin{array}{r}12.806 \\
(2.04)^{* *}\end{array}$ & $\begin{array}{l}0.035 \\
(0.01)\end{array}$ \\
\hline EIC index * Pol. risk & & & & & $\begin{array}{r}0.232 \\
(-2.17)^{* *}\end{array}$ & $\begin{array}{r}0.097 \\
(-1.95)^{*}\end{array}$ \\
\hline Real interest rate & $\begin{array}{l}-0.281 \\
(-1.60)\end{array}$ & $\begin{array}{r}-0.260 \\
(-4.52)^{* * *}\end{array}$ & $\begin{array}{r}-0.215 \\
(-3.79)^{* * *}\end{array}$ & $\begin{array}{r}-0.122 \\
(-5.37)^{* * *}\end{array}$ & $\begin{array}{r}-0.205 \\
(-3.71)^{* * *}\end{array}$ & $\begin{array}{r}-0.116 \\
(-5.18)^{* * *}\end{array}$ \\
\hline GDP growth & $\begin{array}{r}1.865 \\
(5.36)^{* * *}\end{array}$ & $\begin{array}{l}0.264 \\
(1.58)\end{array}$ & $\begin{array}{r}0.875 \\
(2.69)^{* * *}\end{array}$ & $\begin{array}{l}0.069 \\
(0.44)\end{array}$ & $\begin{array}{r}0.868 \\
(2.74)^{* * *}\end{array}$ & $\begin{array}{l}0.092 \\
(0.59)\end{array}$ \\
\hline Labor force part. & $\begin{array}{l}0.038 \\
(0.40)\end{array}$ & $\begin{array}{l}0.158 \\
(1.33)\end{array}$ & $\begin{array}{r}0.439 \\
(3.55)^{* * *}\end{array}$ & $\begin{array}{r}1.006 \\
(3.94)^{* * *}\end{array}$ & $\begin{array}{r}0.452 \\
(3.76)^{* * *}\end{array}$ & $\begin{array}{r}1.123 \\
(4.48)^{* * *}\end{array}$ \\
\hline Political risk & $\begin{array}{r}-0.308 \\
(3.49)^{* * *}\end{array}$ & $\begin{array}{r}0.002 \\
(-0.04)\end{array}$ & $\begin{array}{r}-0.232 \\
(3.5)^{* * *}\end{array}$ & $\begin{array}{r}0.066 \\
(-1.89)^{*}\end{array}$ & $\begin{array}{r}-0.667 \\
(3.17)^{* * *}\end{array}$ & $\begin{array}{r}-0.116 \\
(1.19)\end{array}$ \\
\hline Observations & 100 & 100 & 69 & 69 & 69 & 69 \\
\hline Left hand side & SAVDGDP & SAVDGDP & SAVDGDP & SAVDGDP & SAVDGDP & SAVDGDP \\
\hline$R^{2}$ & 0.385 & 0.938 & 0.528 & 0.926 & 0.561 & 0.930 \\
\hline$\overline{R^{2}}$ & 0.352 & 0.917 & 0.490 & 0.893 & 0.519 & 0.896 \\
\hline
\end{tabular}

Note: The dependent (LHS) variable is the saving rate (\% of GDP). Since the LHS variable is continuous, this panel model was estimated with a least squares specification with or without fixed effects. Details on the panel's structure, and in particular on the construction of the independent variables, are available in section 4. Columns (1)-(2) include the high-income country sample, while columns (3)-(6) include all the non-high-income countries for which the required data was available (the limited number of middle- and low-income countries is due to the scarcity of national income data going back to 1900). The t-stats are denoted in parentheses with the standard statistical significance indicated at the 10,5 , and $1 \%$ levels by $*, * *$, and ${ }^{* * *}$, respectively. 


\section{Appendix of Data Sources}

\begin{tabular}{|l|l|}
\hline Explanatory Variables & Data Source \\
\hline Banking crises onset & Laeven and Valencia (2012) \\
\hline Banking crises history & Laeven and Valencia (2012) \\
\hline Currency crises history & Laeven and Valencia (2012) \\
\hline Duration of banking crises & Laeven and Valencia (2012) \\
\hline Fiscal cost (\% of GDP) & Laeven and Valencia (2012) \\
\hline Non-performing loans (NPL) (\% of assets in banking sector) & Laeven and Valencia (2012) \\
\hline GDP loss (relative to trend, in \%) & Laeven and Valencia (2012) \\
\hline Monetary expansion & Laeven and Valencia (2012) \\
\hline Credit boom (t-1) & Laeven and Valencia (2012) \\
\hline IMF program & imf.org \\
\hline Credit (share of GDP) & Beck and Demirgüc-Kunt (2009) \\
\hline GDP per capita (in constant \$) & World Development Indicators \\
\hline Real GDP per capita growth rate & World Development Indicators \\
\hline Current account balance & World Development Indicators \\
\hline Capital account openness & Chinn and Ito (2006) \\
\hline Exchange rate regime (de facto) & Iltzeki et al. (2011) \\
\hline Hyperinflation (binary) & World Development Indicators \\
\hline EIC index & Barro and Ursua (2011) and WDI \\
\hline Real interest rate & World Development Indicators \\
\hline GDP growth & World Development Indicators \\
\hline Labor force part. & World Development Indicators \\
\hline Political risk & International Country Risk Guides \\
\hline
\end{tabular}

\section{Definition of systemic banking crises (from Laeven and Valencia, 2012)}

A banking crisis is defined as systemic if two conditions are met:

1) Significant signs of financial distress in the banking system (as indicated by significant bank runs, losses in the banking system, and/or bank liquidations)

2) Significant banking policy intervention measures in response to significant losses in the banking system.

Possible policy interventions in the banking sector:

1) extensive liquidity support

2) bank restructuring

3) significant bank nationalizations

4) significant guarantees put in place

5) significant asset purchases (at least 5 percent of GDP)

6) deposit freezes and/or bank holidays.

The first year that both criteria are met is defined to be the year when the systemic crisis started. The observations for the following years in which the banking crisis is still continuing (according to the Laeven and Valencia, 2012, dataset) are removed from the panel sample. The end of a crisis is defined as "the year before both real GDP growth and real credit growth are positive for at least two consecutive years." 